\title{
The use of remote-sensing data for mass-balance studies at Mýrdalsjökull ice cap, Iceland
}

\author{
Julia JAENICKE, ${ }^{1}$ Christoph MAYER, ${ }^{2}$ Kilian SCHARRER, ${ }^{1}$ Ulrich MÜNZER, ${ }^{1}$ \\ Ágúst GUDMUNDSSON ${ }^{3}$ \\ ${ }^{1}$ Department of Earth and Environmental Sciences, Ludwig-Maximilians University, \\ Luisenstrasse 37, D-80333 Munich, Germany \\ E-mail: julia.jaenicke@gmx.de \\ ${ }^{2}$ Commission for Glaciology, Bavarian Academy of Sciences, Alfons-Goppel-Strasse 11, D-80539 Munich, Germany \\ ${ }^{3}$ Fjarkönnun ehf., Furugrund 46, IS-200 Kópavogur, Iceland
}

\begin{abstract}
A series of satellite images of Mýrdalsjökull, Iceland, was analyzed in view of their value for mass-balance investigations. A combination of optical satellite images from the ASTER sensor and synthetic aperture radar data from ERS-2 and Envisat ASAR proved very useful. The glacier margin of Mýrdalsjökull was delineated on ASTER images from summer and winter 2004. With a time series of summer ASAR images it was possible to monitor the temporal and spatial development of the transient snowline (TSL) throughout the year 2004, as well as the firn line (FL) at the end of the balance year. An 'inverse' function was applied to visually enhance detail in the radar imagery. Winter radar images were not useful for mass-balance observations because of frequent surface melting, which prevented the transparency of the snow cover for C-band microwaves. Interannual mass-balance fluctuations were observed by comparing three radar images acquired in late summer 1998, 1999 and 2004 respectively. These fluctuations follow the same trend as the annual mean air temperature which shows a strong increasing trend between 1999 and 2004. An accumulation-area ratio of $<0.43$ was determined for 2004, indicating clear negative mass-balance conditions. Monitoring the TSL-FL with radar summer images for mass-balance studies, rather than the equilibrium line (EL), is suggested for large ice caps in maritime climates.
\end{abstract}

\section{INTRODUCTION}

Global warming has accelerated noticeably in the past 25 years. Model simulations indicate a rise in mean global surface air temperature by about $0.18-0.35^{\circ} \mathrm{C}$ per decade during the next 100 years due to increasing concentrations of $\mathrm{CO}_{2}$ and other greenhouse gases in the atmosphere (Houghton and others, 2001). One of the most visible consequences of climate warming is the retreat of glaciers. Monitoring the mass balance of the temperate glaciers in Iceland is interesting. These glaciers are very sensitive to climatic changes due to marine conditions in Iceland. Most of the Icelandic glaciers have been retreating since about 1995, following a continuous warming since the mid-1980s (Jóhannesson and Sigurðsson, 1998). The Icelandic climate is very sensitive to changes in atmospheric circulation and ocean currents in the North Atlantic (Mackintosh and others, 2002). Consequently, glacier reactions in Iceland could indicate changes of these circulation patterns which are linked to global climate variations. Furthermore, the massbalance status and the glacier runoff are important to the management and planning of hydropower, which is of great economic value to Iceland.

The aim of this study is to investigate the feasibility of using remote-sensing data (space-borne optical and radar) for continuous glacier mass-balance monitoring in south Iceland. Satellite imagery enables continuous monitoring of large, remote areas. An advantage of radar over optical data is the independence from cloud cover and daylight. Synthetic aperture radar (SAR) microwaves can penetrate through clouds and also dry snow. However, on SAR images it is often difficult to delineate the glacier margin because of poor backscatter contrast between the glacier terminus and the surrounding moraine. In this case, optical imagery proves very useful, as was shown by Hall and others (2000) for Hofsjökull ice cap, Iceland. On the other hand, glacier ice and wet snow or firn can be discriminated on radar images. Thus, the annual evolution of the transient snowline (TSL) and the firn line (FL), if exposed in summer, can be monitored (e.g. Rott and Mätzler, 1987; König and others, 2001; de Ruyter de Wildt and Oerlemans, 2003). Most of the preceding work relating radar backscatter to glacier surface and near-surface characteristics analyzed $\sigma^{0}$ backscatter images ( $\mathrm{dB}$ values) in order to separate the glacier into different zones. For example, Forster and others (1996) concluded from investigating Hielo Patagónico Sur (HPS; the South Patagonia Icefield) with shuttle imaging radar (SIR-C/ $\mathrm{X}$-SAR) imagery that $\sigma^{0}$ changes are closely linked to elevation and air temperature. Hall and others (2000) showed the same for Hofsjökull ice cap by analyzing a European Remote-sensing Satellite (ERS) SAR time series. In addition, they investigated the late-summer FL. Fahnestock and others (1993) found distinct glacier surface boundaries on the Greenland ice sheet with ERS-1 SAR data and suggested that monitoring the location of the boundaries can reveal changes in local climate conditions long before they result in a change in the ice-sheet geometry or dynamic. A few studies utilized a combination of optical and radar imagery for glacier investigations (e.g. Hall and others, 2000; de Ruyter de Wildt and Oerlemans, 2003).

This study uses optical data from the Advanced Spaceborne Thermal Emission and Reflection Radiometer (ASTER) 


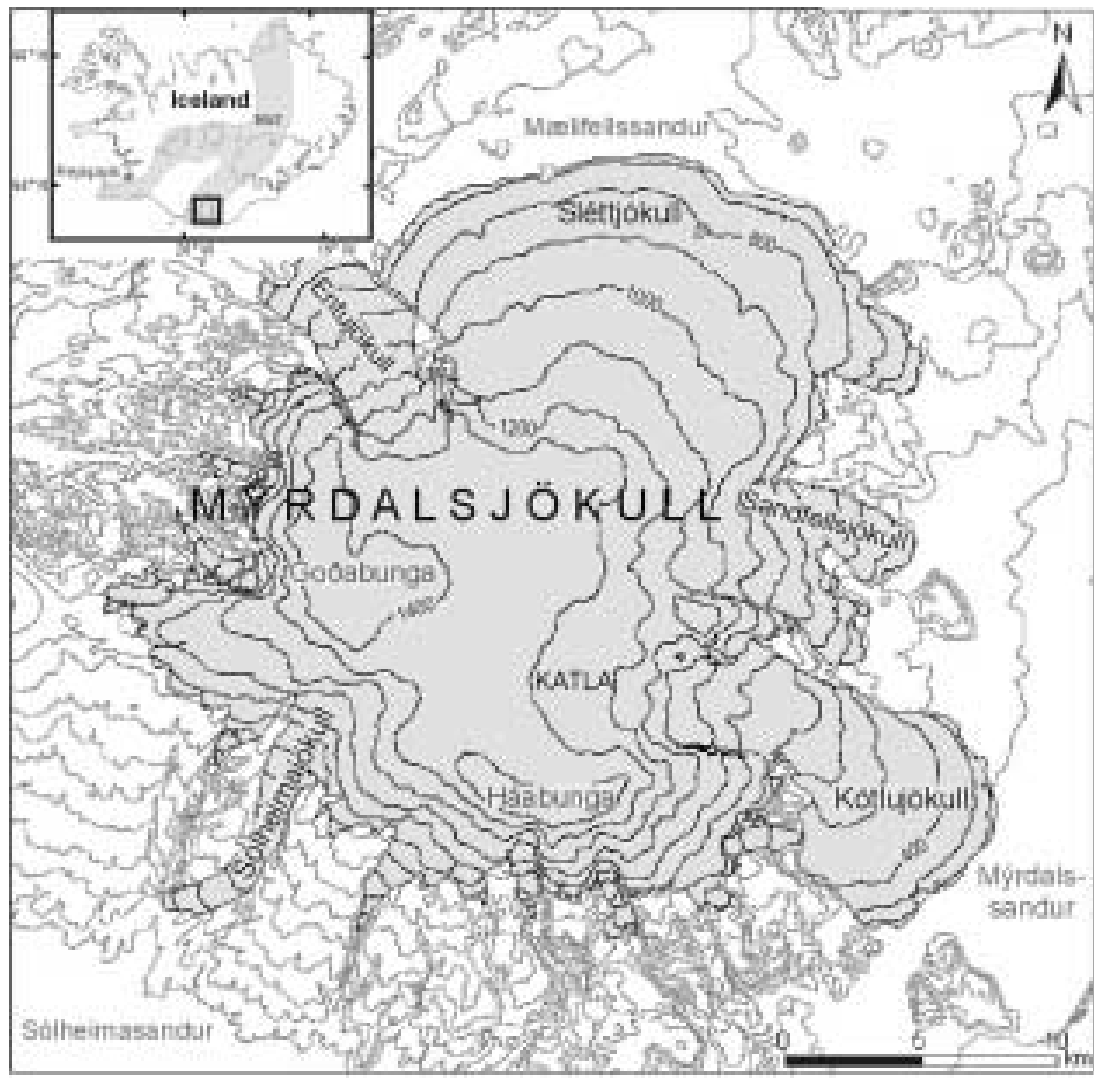

Fig. 1. The location of Mýrdalsjökull on the south coast of Iceland and in the southeastern part of the neovolcanic zone. The ice cap is characterized by a high, flat central part surrounded by a radial system of outlet glaciers. The margin is delineated from 2004 ASTER images; height contours from a DEM based on DMA (1990).

to delineate the glacier margin and determine the area extent of Mýrdalsjökull ice cap, Iceland. Furthermore, Envisat Advanced SAR (ASAR) data from 2004 and ERS-2 SAR data from earlier years are visually analyzed for snowand firn-line monitoring. For this we used the findings of previous work regarding the radar-backscatter/glaciersurface interaction and then concentrated on the digital mapping of the detectable glacier zones. These data were implemented in a Geographical Information System (GIS) for further analysis and comparison. Thus, mass-balance conditions could be investigated qualitatively and then linked to weather data from nearby stations.

\section{STUDY AREA}

Mýrdalsjökull, the fourth largest ice cap in Iceland, has an area of about $590 \mathrm{~km}^{2}$ (Fig. 1). It is located on the south coast of the island $\left(63^{\circ} 40^{\prime} \mathrm{N}, 19^{\circ} 05^{\prime} \mathrm{W}\right)$ and at the southeastern end of the neovolcanic zone. The glacier ice covers the active volcano Katla which last erupted in 1918. Two eruptions have occurred within the Katla system every century on average during the last 1100 years (Larsen, 2000). Therefore, an eruption is expected in the near future. In addition, deloading due to a glacier mass loss induced by climate warming is also considered as a possible triggering mechanism for a future eruption (Sigvaldason and others, 1992).

This study visually analyzes the entire Mýrdalsjökull ice cap. Morphologically the ice cap can be divided into a plateau, where the ice forms a contiguous cover down to about 1300-1000 ma.s.l., and the peripheral zone below, where the ice cap splits into separate outlet glaciers (Fig. 1).
Ice lobes exist in the east and the north, such as Sléttjökull with a slope of $<5^{\circ}$. Outlet glaciers on the western and southern side are much steeper. Sólheimajökull in the southwest shows typical characteristics of the tongue of a valley glacier. It terminates at $120 \mathrm{~m}$ a.s.I., the lowest point of Mýrdalsjökull, while the highest point is at about $1500 \mathrm{~m}$ a.s.l. (Goðabunga). Orographic effects are important due to the mountainous topography. The windward southeastern slopes receive more snowfall than the northwestern slopes in the lee of the ice cap itself. This affects the position of the snow-/firn line. Temperature is mild for the latitude, due to the moderating influence of North Atlantic Drift waters that extend around the south coast of Iceland (warm Irminger current). The combination of warm ocean waters and a general southeasterly wind direction leads to a very high annual precipitation of $>4000 \mathrm{~mm}$ on the southeastern slopes of Mýrdalsjökull and at least $2000 \mathrm{~mm}$ on the northwestern side (Mackintosh, 2000). More than $80 \%$ of the annual precipitation falls between September and May (Björnsson, 1979).

There are no in situ mass-balance data available for Mýrdalsjökull, and very few remote-sensing data of the ice cap have been analyzed so far (two ERTS-1 (Landsat) images from 1973 by Crabtree (1976); one Multispectral Scanner Landsat image from 1973 by R.S. Williams in Björnsson (1978); and one ERS-2 image from 1996 by Brown (1998), used for glacier extent and surface studies). Terminus fluctuations of Sólheimajökull have been manually measured since 1930. A retreat of $342 \mathrm{~m}$ between 1996 and 2004 has been recorded, with the largest annual retreat, $92 \mathrm{~m}$, in 2003 (Sigurðsson, 1998, 1999, 2000a, b, 2001, 2002, 
2003a, b, 2004, 2005). Due to the large size and inaccessibility of Mýrdalsjökull, the use of remote-sensing methods for investigating the whole ice cap is recommended.

\section{DATA}

\subsection{Satellite images}

Of all recorded ASTER images of Mýrdalsjökull from the launch of the Terra satellite in December 1999 until the end of 2004, there are only five useful, i.e. cloud-free, scenes. The resolution of the ASTER images is $15 \mathrm{~m}$ in the visible and very near-infrared spectrum (bands $1-3$ ). These three bands were used to determine the glacier margin.

Due to frequent cloudiness in Iceland, radar imagery is very valuable for continuous monitoring of Mýrdalsjökull ice cap. The Envisat satellite, launched in March 2002, carries the ASAR sensor in continuation of the ERS-2 SAR mission. Data from these two radar sensors were used for this study. In total, 25 images of Mýrdalsjökull, most of them from 2004, were available (Table 1). The ERS-2 SAR and Envisat ASAR data were ordered as single look complex (SLC) images and processed to a pixel size of $12 \mathrm{~m}$. Both radar sensors operate in C-band at a wavelength of $5.6 \mathrm{~cm}$. All radar images used were acquired with vertical transmit-andreceive (VV) polarization. While ERS-2 scenes are imaged with a mean look angle of $23^{\circ}$, the ASAR antenna is steerable and seven different look angles (IS1-IS7, 14-45 ) can be chosen by the user. The ASAR images of Mýrdalsjökull were ordered in image modes IS2 $\left(23^{\circ}\right)$ and IS5 $\left(38^{\circ}\right)$. Thus, a continuous ASAR data series for the year 2004 was built up with a temporal resolution of up to 9 days, including ascending (asc.) and descending (desc.) orbits (Table 1). The series was used for monitoring dynamic surface changes over 2004. In addition, two ERS-2 images from the end of mass-balance years 1997/98 and 1998/99, respectively, were used for investigating longer-term mass-balance fluctuations. For this study, there was no further SAR imagery available that could have been used to investigate other mass-balance years.

\subsection{Additional data and image processing}

Topographic maps from 1990 (DMA, 1990) were used to generate a digital elevation model (DEM) and for subsequent orthoprojection of all available satellite imagery, based on a common map projection (Universal Transverse Mercator, WGS84 zone 28). For the ASTER images a horizontal and vertical referencing accuracy of $<15 \mathrm{~m}$ ( 1 pixel), i.e. displacement between image and reference map, was achieved. In order to optimize geocoding of the radar images, ten corner reflectors were used. These corner reflectors were installed in 1995 on five positions around Mýrdalsjökull. At each location, one reflector was orientated towards the ascending orbit and another towards the descending orbit. The corner reflectors are clearly identifiable points on the ERS-2 and ASAR images and therefore serve as high-quality ground-control points (GCPs). Due to the lack of infrastructure in the area surrounding the glacier (resulting in no easily identifiable features for GCPs), geocoding without corner reflectors would be difficult, time-consuming and imprecise. However, an accuracy of less than 1 pixel, i.e. $12 \mathrm{~m}$, was achieved with the help of corner reflectors. The geocoding of some winter images required the use of topographic maps in addition to corner
Table 1. ERS-2 SAR, Envisat ASAR and Terra ASTER images of Mýrdalsjökull used in this study

\begin{tabular}{|c|c|c|}
\hline Year & Date & Sensor \\
\hline $\begin{array}{l}1998 \\
1999 \\
2003 \\
2004\end{array}$ & $\begin{array}{l}21 \text { August } \\
22 \text { August } \\
4 \text { February } \\
9 \text { January* } \\
17 \text { March } \\
11 \text { April } \\
23 \text { April } \\
2 \text { May } \\
16 \text { May } \\
28 \text { May } \\
6 \text { June } \\
20 \text { June } \\
21 \text { June } \\
6 \text { August } \\
29 \text { August } \\
10 \text { September } \\
19 \text { September } \\
23 \text { September } \\
15 \text { October } \\
24 \text { October* } \\
25 \text { October } \\
7 \text { November } \\
19 \text { November* } \\
28 \text { November* } \\
24 \text { December* }\end{array}$ & $\begin{array}{l}\text { SAR } \\
\text { SAR } \\
\text { ASTER } \\
\text { ASAR IS5 desc.* } \\
\text { ASTER } \\
\text { ASAR IS5 asc. } \\
\text { ASAR IS5 desc. } \\
\text { ASAR IS2 desc. } \\
\text { ASAR IS5 asc. } \\
\text { ASAR IS5 desc. } \\
\text { ASAR IS2 desc. } \\
\text { ASAR IS5 asc. } \\
\text { ASTER } \\
\text { ASAR IS5 desc. } \\
\text { ASAR IS5 asc. } \\
\text { ASAR IS5 desc. } \\
\text { ASAR IS2 desc. } \\
\text { ASTER } \\
\text { ASAR IS5 desc. } \\
\text { ASAR IS2 desc.* } \\
\text { ASTER } \\
\text { ASAR IS5 asc. } \\
\text { ASAR IS5 desc.* } \\
\text { ASAR IS2 desc.* } \\
\text { ASAR IS5 desc.* }\end{array}$ \\
\hline
\end{tabular}

Note: ASAR images acquired during freezing conditions over the high, flat central part of Mýrdalsjökull are marked *.

reflectors, as some of the reflectors were not visible, possibly because they were filled with wet or heavily metamorphosed snow, preventing sufficient backscatter.

After the geocoding, a few satellite images had to be coregistered, i.e. made to conform to each other to remove slight displacements between the images. This is very important for boundary delineation and comparison. It has to be mentioned that the radar images were not radiometrically corrected, and thus no $\sigma^{0}$ backscatter images ( $\mathrm{dB}$ values) were generated. This processing step is only necessary for quantitative, not for visual, image analyses.

In addition to the satellite imagery, oblique photography from an aerial survey in 2004 and local knowledge was helpful for delineating the glacier margin in questionable regions on the ASTER images. Weather data from eight nearby weather stations, of which seven are located south and one east of Mýrdalsjökull, were obtained from the Icelandic Meteorological Office. For the year 2004, hourly and daily data of different meteorological parameters (e.g. temperature, precipitation and wind) were available. Monthly mean values of temperature and precipitation, recorded since 1961 at two nearby weather stations (Vatnsskarðshólar and Vík), were downloaded from the Internet (http://www.vedur.is).

\section{RADAR IMAGE ENHANCEMENT}

After geocoding and co-registration, an image enhancement operation was applied to the summer radar scenes. Various techniques were tested in order to optimize the contrast between wet snow and glacier ice for visual boundary detection. The following three-step method was found to be 


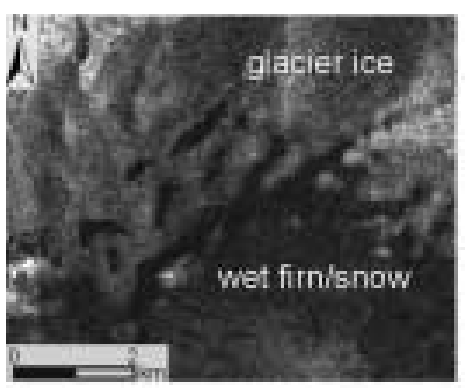

a original

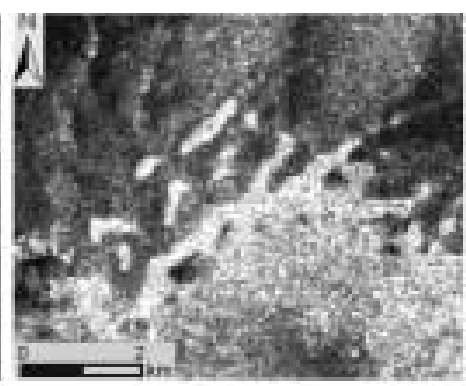

b inverse

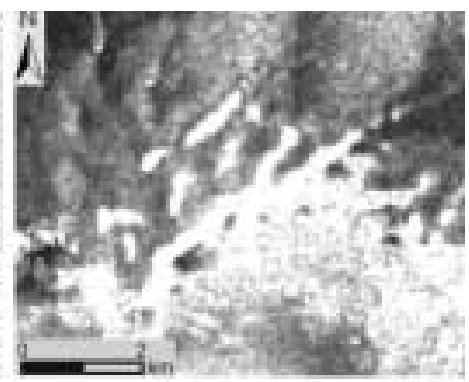

c. Lee sigma $3 \times 3$ and $5 \times 5$

Fig. 2. (a) A $6 \times 7.5 \mathrm{~km}$ detail of an ASAR image of Sléttjökull, acquired on 10 September 2004. (b, c) Image enhancement for the boundary detection between wet firn/snow and glacier ice on Mýrdalsjökull by first generating an 'inverse' image (b) and then running a Lee sigma filter with a $3 \times 3$ and $5 \times 5$ window (c). (C) European Space Agency 2004.

the best: First, an 'inverse' image is generated (default function available in ERDAS Imagine), then a Lee sigma filter is applied twice, using a $3 \times 3$ window, followed by a $5 \times 5$ window. 'Inverse' is a brightness inversion function which emphasizes detail that would otherwise be lost in the lowdigital-number (low-DN) (dark) pixels. In addition, the input data range (DN 0-255) is scaled to 0-1.0. The Lee sigma filter reduces the radar speckle, i.e. areas become more homogeneous and boundaries are sharpened. The result of these image enhancement steps is illustrated in Figure 2.

\section{IMAGE ANALYSIS}

After image processing, boundaries were manually digitized on the satellite images in ESRI's ArcGIS environment. While the ASTER images were used for delineating the glacier margin, the glacier surface changes were monitored using the radar images.

\subsection{Glacier margin}

To delineate the whole glacier margin of Mýrdalsjökull ice cap, four ASTER images from 2004 were necessary (Table 1). Most of the glacier margin was detected on the image acquired on 23 September 2004. However, additional data were needed because of clouds over the southern outlet glaciers on that scene and due to debris cover on the glacier front of Sléttjökull in the north and Kötlujökull in the southeast. Debris cover is not distinguishable from the glacier forefield on summer images. However, the debriscovered glacier margins were clearly detectable on the winter images because the two outlet glaciers terminate on a sandur plain, forming a distinct topographic edge. It is assumed that the regional-margin changes within the observation period (March-October) are not considerably larger than the ASTER image resolution, which allows us to produce a continuous glacier margin for 2004.

\subsection{Snow-/firn-line monitoring}

In late summer, only two glacier facies can be observed on Mýrdalsjökull: the wet-snow facies and the ablation facies (classification according to Benson, 1962; Williams and others, 1991). This is typical for temperate glaciers (Paterson, 1981). The wet-snow facies consists of melting snow and/or melting firn. Firn is defined as snow that is at least 1 year old, to distinguish it from snow fallen in the mass-balance year under consideration (Oerlemans, 2001). At the end of a mass-balance year, the wet-snow facies and the ablation facies, i.e. the bare glacier ice, are separated either by the TSL or, if firn is exposed, by the $\mathrm{FL}$, depending on the weather conditions during the ablation season. The discrimination of snow and firn is important for the detection of the equilibrium line (EL). The EL equals the TSL at the end of a balance year, and its position contains information about the mass balance.

The boundary between the wet-snow facies and the ablation facies is detectable on radar images (e.g. Rott and Mätzler, 1987; Hall and others, 1995). The discrimination of wet-snow facies and glacier ice is based on the difference in their backscatter intensity: wet snow absorbs the radar signal, while glacier ice shows strong backscattering due to surface roughness. However, it is not possible to discriminate snow and firn on single-polarized C-band radar images due to similar backscatter values (e.g. König and others, 2001; de Ruyter de Wildt and others, 2002). Consequently, the TSL or EL at the end of the mass-balance year is only visible on radar images if no firn is exposed at the glacier surface. Nevertheless, the temporal and spatial evolution of the TSL, which varies each year, also contains information about the mass balance of a glacier. De Ruyter de Wildt and Oerlemans (2003) explain that the TSL or FL on a glacier separates the area of high albedo (snow/firn) and relatively low albedo (ice) which strongly determines the amount of surface melt and hence the mass balance. In addition, the evolution of the TSL reflects the accumulation history of the preceding winter. As the TSL position affects the amount and timing of seasonal melt discharge, its evolution yields interesting information for hydrologic research.

Since the boundary between wet snow and bare ice on radar summer images is either the TSL or the $\mathrm{FL}$, it is abbreviated to TSL-FL (first used by de Ruyter de Wildt and Oerlemans, 2003) in this study. Furthermore, the term 'radar glacier zones', introduced by Forster and others (1996) and also used by other authors (e.g. Forster and others, 1997; Smith and others, 1997; Ramage and others, 2000), was found to be more appropriate than using the glaciological facies definition. In contrast to the glacier facies, which imply an annual timescale, the radar glacier zones develop on a timescale of days and weeks. Forster and others (1996) define four radar glacier zones which they found on the temperate HPS by comparing C- and L-band imagery from the space-shuttle missions in 1994: a relatively dry-snow zone, a moderately wet-snow zone, a wet-snow zone (with weak returns in both bands) and a bare-ice zone (with strong returns in both bands). Analyzing C-band data, on 
Mýrdalsjökull only a wet-snow zone and a bare-ice zone can be observed. At the end of the melt season, these zones equal Benson's wet-snow and ablation facies, respectively. Smith and others (1997) show for the Stikine icefields, British Columbia, Canada, that meltwater production is affected by the development of these radar glacier zones.

In this study, the TSL-FL, separating the wet-snow zone and the bare-ice zone, was manually delineated on seven ASAR summer images of Mýrdalsjökull, acquired between 11 April and 10 September 2004. The latter image marks the end of mass-balance year 2003/04 due to snowfall on 16 and 17 September below the FL and a consecutive snow cover throughout the winter. The TSL-FL was also clearly detectable on the ERS-2 images from the end of August 1998 and 1999. It was found that ASAR IS5 descending images are preferable over ascending and IS2 images for TSL-FL digitizing due to the topography of Mýrdalsjökull with its steep western outlet glaciers. These cause sensor oversaturation due to topographic foreshortening and layover.

On three summer images, acquired during the 2004 melt season, the TSL-FL could not be detected due to areas within the wet-snow zone that show unusually high backscatter values, similar to those of the glacier ice. Bright areas within the otherwise dark wet-snow zone are also visible on other summer images, but there they do not disturb the course of the TSL-FL. De Ruyter de Wildt and Oerlemans (2003) found similar bright backscatter areas within the wetsnow zone on 5 out of 43 ERS-1/-2 SAR summer images of Vatnajökull ice cap, located northeast of Mýrdalsjökull (see Fig. 1). Analyzing the weather data from stations close to Mýrdalsjökull, the isolated high backscatter values seem to be caused by increased surface roughness or a decrease in snow wetness due to special weather conditions such as a rainstorm, a strong temperature drop (refreezing), or a dust storm from the sandur plains. These are only short-term events and therefore alter the radar glacier zones only for a few hours or days. In the case of a rainstorm and a sharp temperature decrease, this is confirmed by Forster and others (1997) using sub-daily space-shuttle SAR imagery for investigating HPS. Due to the isolated bright areas within the wet-snow zone on Mýrdalsjökull, automatic zone detection with a $k$-means algorithm could not be successfully applied over the glacier surface.

Since the C-band SAR signal is able to transmit through dry snow, often winter images are used to detect the position of the EL or FL from the end of the mass-balance year (e.g. König and others, 2001; Engeset and others, 2002; Storvold and others, 2005). In the case of Mýrdalsjökull, however, winter radar images are not useful for mass-balance observations because melting conditions also occur frequently in the winter (see Table 1). Thus, the winter snow cover is no longer transparent for C-band radar.

\section{RESULTS}

\subsection{Estimation of errors}

All processing steps introduce some uncertainty in the area measurements. However, all area uncertainties are small compared to the large area of Mýrdalsjökull and its wetsnow zone. Two kinds of errors can be discriminated: systematic and random errors. The latter are introduced by the analyst during the mapping of glacier boundaries on the satellite images. Systematic errors result from the spatial resolution of the satellite data, the DEM resolution and generation as well as the geocoding of the imagery. There is a maximum displacement error of $\pm 12 \mathrm{~m}$ for ERS-2 SAR and Envisat-ASAR data and $\pm 15 \mathrm{~m}$ for ASTER data. The displacement error introduced by the DEM resolution is $\pm 20 \mathrm{~m}$ in the vertical and $\pm 12 \mathrm{~m}$ in the horizontal direction. From the DEM generation an error of $\pm 2.6 \mathrm{~m}$ in height (from digitizing contour lines) plus an unknown interpolation error has to be added. The geocoding accuracy is \pm 1 pixel for all used imagery. After orthoprojection the accuracy must be reduced to less than 1 pixel.

Thus, delineation of the glacier margin on $15 \mathrm{~m}$ resolution ASTER images results in an error of $\pm 4 \mathrm{~km}^{2}$ for the glacier area. The DEM used in this study is the largest source of error for the calculation of glacier areas. This is due to elevation changes of the ice cap in recent years. A maximum error of $1.5 \%$ is estimated for the whole glacier area. The relative accuracy of the results, however, is very high due to the use of corner reflectors for radar image geocoding, which allows a highly precise (sub-pixel) co-referencing of the individual radar images.

\subsection{Area of Mýrdalsjökull}

It is important to know the present area of a glacier for a quantitative mass-balance comparison with past and future years which can then be related to a climatic change. The glacier area is needed for determining the accumulationarea ratio (AAR), a characteristic of glacier mass balance (see section 6.4). By delineating the glacier margin of Mýrdalsjökull on ASTER images and combining it with the existing DEM, a total glacier area of $586 \pm 13 \mathrm{~km}^{2}$ was determined for 2004. At the beginning of the 20th century, the area was about $700 \mathrm{~km}^{2}$, measured from topographic maps (Björnsson, 1978). The extent of the glacier then shrank to about $596 \mathrm{~km}^{2}$ in 1973, as determined from a Landsat satellite image ( $80 \mathrm{~m}$ resolution) by R.S. Williams (in Björnsson, 1978) (the error margin is estimated to be $\pm 22 \mathrm{~km}^{2}$, resulting from the coarse image resolution). The area reduction of Mýrdalsjökull in the second half of the 20th century, compared to the first half, corresponds to in situ measurements of the Sólheimajökull terminus (Sigurðsson, 1998). Such long-term glacier variations can be investigated by monitoring the glacier area. However, for short- and medium-term reactions of a glacier to changes in climatic conditions, it is necessary to measure the mean specific mass balance $\left(B_{\mathrm{m}}\right)$. Without having in situ $B_{\mathrm{m}}$ data, as in the case of Mýrdalsjökull, the AAR is a suitable parameter for describing the state of a glacier. The AAR, determined from the calculated equilibrium-line altitude (ELA), and $B_{\mathrm{m}}$ correlate significantly (Oerlemans, 2001). The use of SAR data for AAR determination is discussed in section 6.4. The next subsection shows the results of the radar glacier zone analysis by comparing snow- and firn lines as well as investigating their position and evolution within a Geographical Information System (ArcGIS by ESRI).

\subsection{The snow- and firn lines in $\mathbf{2 0 0 4}$}

Figure 3 shows the result of the ASAR 2004 summer image analysis as described above. On six summer images, the boundary between the wet-snow zone and the glacier ice zone was digitized to monitor the spatial and temporal evolution of the TSL-FL. During the melt period, a reduction of the wet-snow zone by $335 \mathrm{~km}^{2}$ was measured, with the largest daily area loss in June (see Table 2), even though the 


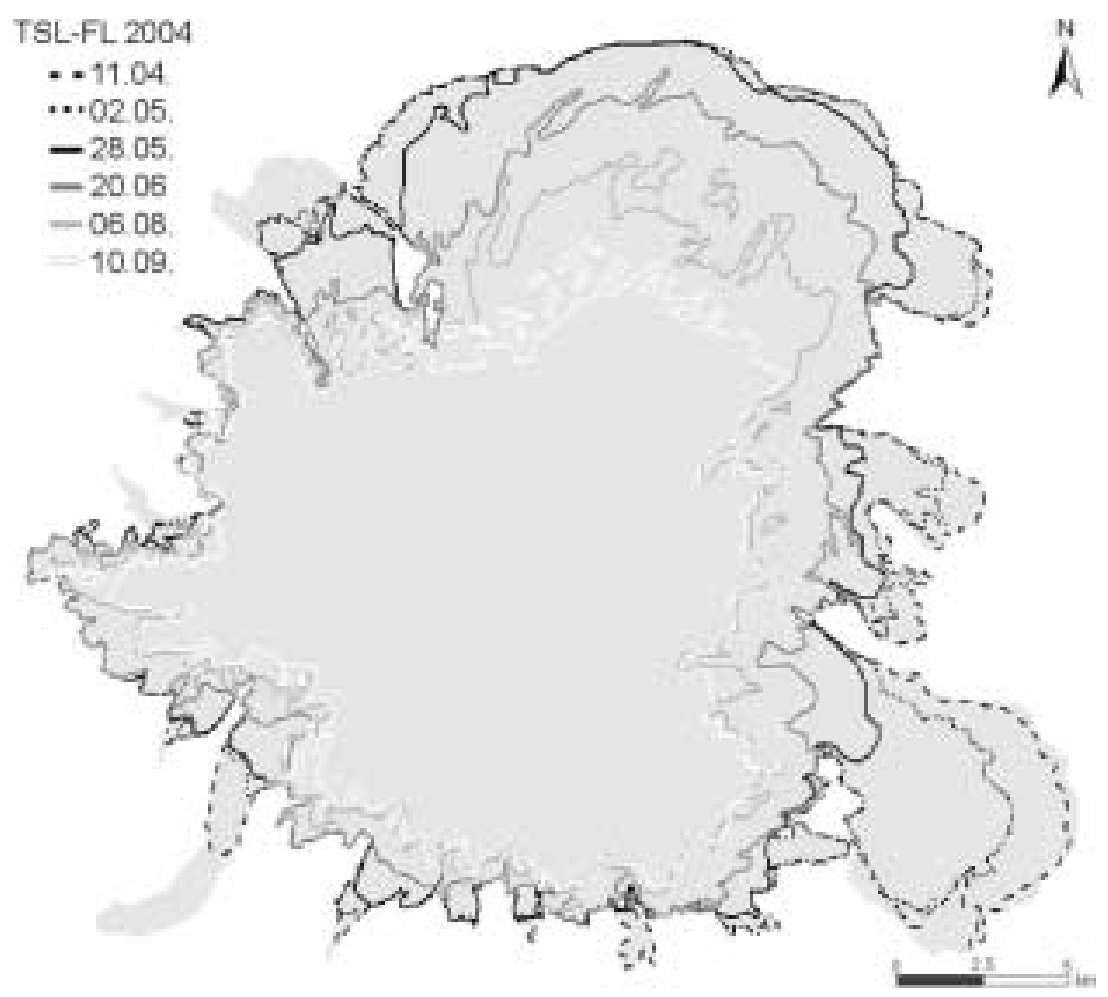

Fig. 3. Retreat of the TSL-FL on Mýrdalsjökull, 11 April-10 September 2004 (boundaries delineated on ASAR images). Dates are dd/mm.

highest air temperatures were reached in August. This indicates that firn was exposed on the glacier surface in summer 2004. In general, the FL maintains a more stable position than the TSL, because of higher densification of the snowpack and thus lower melt rates. Furthermore, 2004 was an unusually warm year. Therefore, the boundary of the wetsnow zone, as determined from the 10 September 2004 radar image (white in Fig. 3), is assumed to be the latesummer FL. For this situation, the FL represents the theoretical maximum extent of the accumulation area. A more accurate position of the EL cannot be derived from the analysis of the 2004 ASAR single-polarized C-band imagery. The altitude of the FL varies over the large ice cap due to orographic effects. In 2004, its lowest position, 1020 m a.s.I., is on Kötlujökull outlet glacier, which is located on the

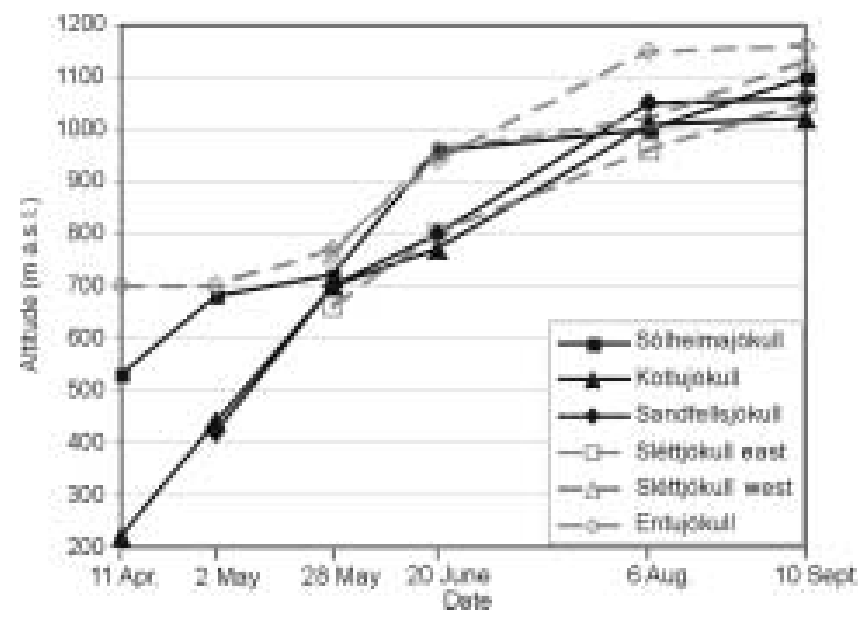

Fig. 4. Development of the TSL-FL altitude on various outlet glaciers of Mýrdalsjökull in 2004 (for glacier location see Fig. 1). maritime and windward eastern side of Mýrdalsjökull. It reaches a maximum of $1160 \mathrm{~m}$ a.s.I. on Entujökull, located on the more continental and drier northwestern side. On Sléttjökull the transition between the windward and the lee exposition of the glacier is visible, where the FL gradually decreases in altitude from west to east (Fig. 3). The position of the $\mathrm{FL}$, influenced by the mountainous topography of the ice cap, can best be investigated when overlain on the DEM and displayed in three dimensions (e.g. using the program ArcScene within ArcGIS).

Figure 4 illustrates the development of the TSL-FL altitude during the 2004 melt season on six outlet glaciers of Mýrdalsjökull. Due to the different topographic influences on Sléttjökull, the glacier has been separated into an eastern and western part. Figure 4 demonstrates that changes in the TSL-FL altitude are in general reduced between 6 August and 10 September. It is assumed that in late July the TSL reaches the FL. Afterwards the wet-snow zone consists of snow and firn which cannot be distinguished. Figure 4 also shows that for most of the melt season the TSL-FL is at higher altitudes on Sólheimajökull than on the other windward outlet glaciers (Kötlujökull, Sandfellsjökull, Sléttjökull east). This is probably due to higher direct and indirect sun irradiance because of its south-facing slopes and the proximity of the ocean.

As already mentioned, the TSL-FL contains information about the mass balance of a glacier since it separates highand low-albedo zones and shows an annual evolution characteristic of the balance year under investigation. Many glaciological studies use the ELA to infer the mean specific mass balance. However, de Ruyter de Wildt and Oerlemans (2003) have successfully correlated the average altitude of the TSL-FL, derived from ERS SAR images, during the second half of the melt season with in situ mean specific mass-balance $\left(B_{\mathrm{m}}\right)$ values for some drainage basins of 


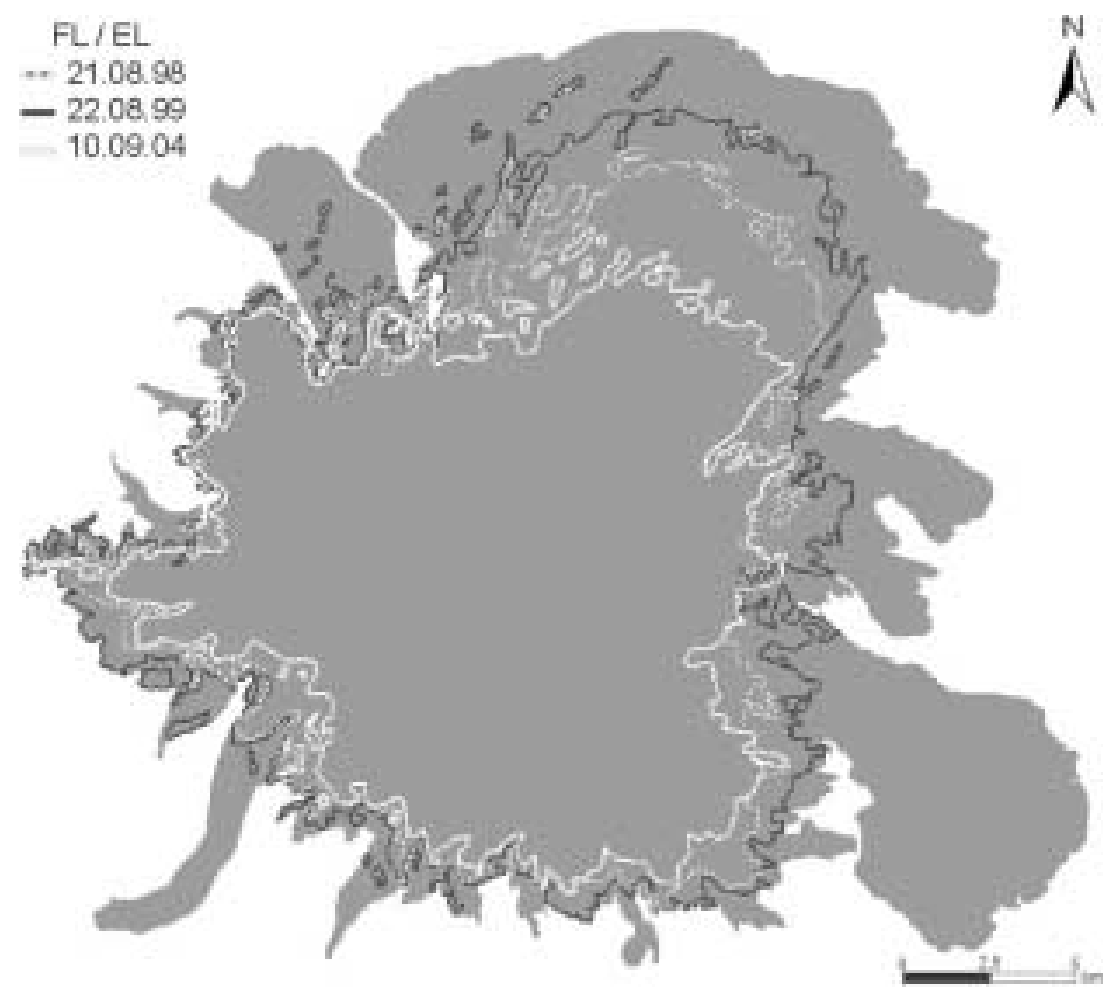

Fig. 5. Three different mass-balance situations of Mýrdalsjökull at the end of melt seasons 1998, 1999 and 2004. There is a clear difference in the position of the FL/EL between the individual years, and thus in the glacier mass balance. Boundaries delineated on two ERS-2 images and one ASAR 2004 image. Dates are dd.mm.yy.

Vatnajökull. For this study, it would be interesting to test the relationship between $B_{\mathrm{m}}$ and the temporal evolution of the wet-snow zone. In this case, no smoothing of the TSL-FL altitude would be necessary, and the method could be applied to large entire ice caps like Mýrdalsjökull. However, this method requires in situ $B_{\mathrm{m}}$ values which are not available for Mýrdalsjökull.

\subsection{Mass-balance fluctuations}

In Figure 5, the wet-snow/bare-ice zone boundaries delineated on the late-summer radar images from 10 September 2004, 21 August 1998 and 22 August 1999 are displayed together for relative mass-balance investigations. Snowfall on Mýrdalsjökull occurs mainly between September and April, i.e. the mass-balance year generally ends in early September. From analyzing the evolution of the 2004 radar glacier zones (see section 5.2), it is obvious that the melt season ended at the beginning of September 2004 at the latest. A comparison of all available summer radar images shows that in early August 2004 the TSL-FL had already reached a higher elevation than in the late-August images of 1998 and 1999. Moreover, the air temperatures recorded at Vatnsskarðshólar station, located $13 \mathrm{~km}$ south of the Mýrdalsjökull glacier margin, show significantly lower August temperatures in 1998 and 1999 compared with 2004 (mean temperature difference of $3.5-4.0^{\circ} \mathrm{C}$ ). Due to the comparatively cold late-summer temperatures, it is assumed that the two late-August images from 1998 and 1999 represent the end of the ablation seasons. Thus, the TSL-FL of these images can be interpreted as the FL or EL of mass-balance years 1997/98 and 1998/99. In Figure 5, a large displacement between the three snow-/firn lines is especially recognizable on the flat and extended Sléttjökull.
The considerable distance between these late-summer snow-/firn lines indicates a distinct mass-balance difference between the three balance years. Given the proximity of the warm ocean and the low altitude of Mýrdalsjökull, high annual mass-balance fluctuations are not surprising.

The late-summer radar imagery of Mýrdalsjökull enables a relative mass-balance comparison without the need for in situ data. The FL in late summer 2004 is clearly located above the other boundaries in Figure 5, i.e. the massbalance year 2003/04 is highly negative compared to 1998 and 1999. Area measurements show that at the end of summer 2004, $124 \mathrm{~km}^{2}$ more glacier ice was exposed to melting than in 1999. The boundary in 1999 is located at a lower elevation than at the end of the previous balance year. Thus, the delineated boundary must be the snowline and represents the EL for the 1998/99 mass-balance year.

Table 2. Areal reduction of the wet-snow zone on Mýrdalsjökull in 2004 as measured on six ASAR images (total glacier area $586 \mathrm{~km}^{2}$ )

\begin{tabular}{lcc}
\hline Date (2004) & Radar wet-snow zone & $\begin{array}{c}\text { Daily area loss between } \\
\text { image dates } \\
\mathrm{km}^{2}\end{array}$ \\
\hline 11 April & 564 & \\
2 May & 539 & 1.2 \\
28 May & 482 & 2.2 \\
20 June & 409 & 3.2 \\
6 August & 305 & 2.2 \\
10 September & 251 & 1.5 \\
& & \\
\hline
\end{tabular}




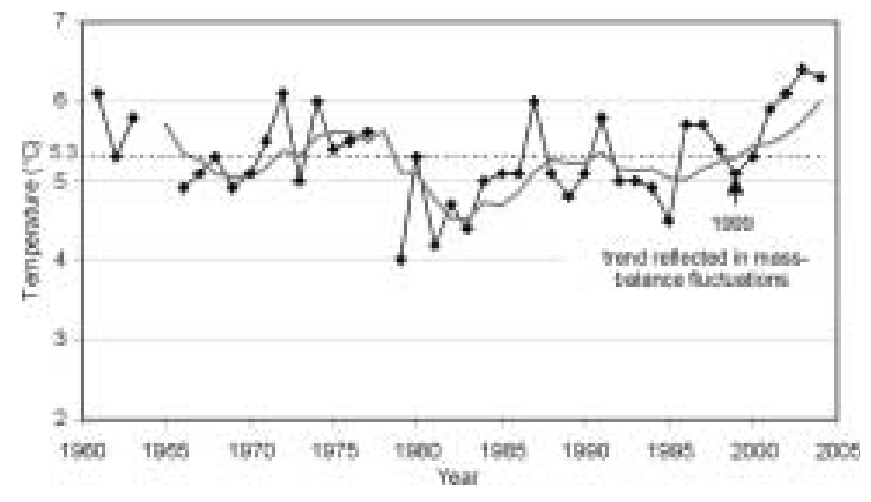

Fig. 6. The annual mean air temperature recorded at Vatnsskarðshólar weather station, 1961-2004 (black lines and symbols). The solid grey line is the running mean over 5 years. The dashed line marks the $5.3^{\circ} \mathrm{C}$ mean of the years $1961-2004$. Data source: Icelandic Meteorological Office.

Compared to the previous year, the balance year 1998/99 is positive, and an AAR of about 0.64 was determined. For 1998 it is not possible to decide whether the detected boundary is the EL or the FL since no further radar imagery from 1998 or 1997 was available for this study. For massbalance year 2003/04 the AAR can only be estimated since the wet-snow zone, as determined from radar image analysis, includes snow from the balance year under investigation and firn from the previous year/s. In 2004 the $E L$ is located somewhere above the $F L$, so the AAR is somewhat smaller than the 'wet-snow zone divided by glacier area'. Since radar imagery can often only detect the FL and not the EL, the term firn-area ratio (FAR) is introduced:

FAR = wet-snow zone (including snow and firn)/glacier area.

This parameter can be applied to mass-balance investigations by means of radar imagery when the mass-balance year under investigation is negative compared to the previous year. At present, this is frequently the case for many glaciers due to the warming climate. In general, the FAR will show smaller annual changes than the AAR since the FL is usually more stable than the EL. At Mýrdalsjökull the FAR for mass-balance year 2003/04 is 0.43 . So far, this is the only available FAR value for Mýrdalsjökull. Therefore, it has to be compared with the AAR which is $<0.43$. This suggests that 2003/04 was a negative mass-balance year since the AAR for zero mass balance is generally 0.5-0.8 for temperate mountain glaciers (Meier and Post, 1962). As a comparison, the trend of $B_{\mathrm{m}}$ values measured at Vatnajökull is similar to the mass-balance observations at Mýrdalsjökull. $B_{\mathrm{m}}$ values of Vatnajökull were measured from 1993 to 1999 (de Ruyter de Wildt and Oerlemans, 2003). Since 1995, negative values have been recorded. The year 1999, with a value of -0.26 mw.e., was less negative than 1998 (-0.77 mw.e.), which is in agreement with our observations.

The mass-balance situation of the three investigated years at Mýrdalsjökull is well reflected in the annual mean air temperatures measured at Vatnsskarðshólar weather station (cf. Figs 5 and 6). The mean temperature in 2004 was $1.2^{\circ} \mathrm{C}$ higher than in 1999 , but 1999 was $0.2^{\circ} \mathrm{C}$ colder than 1998. The mean winter temperatures (NovemberMarch) are low enough in all years to prevent considerable runoff from the glacier, and the annual precipitation does not show significant variation. This suggests that the summer temperatures are the driving factor for massbalance fluctuations at Mýrdalsjökull ice cap. This is in agreement with Jóhannesson and Sigurðsson (1998) who also found a general relation between summer temperatures and glacier fluctuations in Iceland. Furthermore, the duration of the melt season at Mýrdalsjökull has increased in recent years due to increasing mean temperatures in April and September.

\section{CONCLUSIONS}

This study shows that remote-sensing data are of great use for continuous mass-balance monitoring of Mýrdalsjökull. The investigation of this large ice cap $\left(586 \pm 13 \mathrm{~km}^{2}\right)$, which is located in a sparsely populated area, would not be possible without the use of remote-sensing data.

Analysis was carried out on several ASTER images, a time series of Envisat ASAR images for the year 2004 and two ERS-2 SAR images, acquired at the end of mass-balance years $1997 / 98$ and $1998 / 99$, respectively. This combination of optical and radar satellite data proved to be very useful for mass-balance investigations. The sensors acquire different characteristics of the glacier surface and subsurface and thus yield complementary information when combined. With four ASTER images from 2004, the whole glacier margin was delineated and the area of Mýrdalsjökull determined. For glacier margin detection, summer as well as winter optical images are required. It was found that winter SAR images are not useful for mass-balance studies at Mýrdalsjökull because of frequent surface melt conditions even during wintertime. However, with summer SAR images the dynamic glacier surface changes during the ablation season can be continuously monitored. The TSL is detectable as long as no firn is exposed. It is known that wet snow and wet firn cannot be discriminated on single-polarized C-band SAR imagery. Consequently, the $\mathrm{EL}$ is often not detectable because most mass-balance years have been negative for the last decade. Therefore, we suggest mass-balance investigations by monitoring temporal and spatial fluctuations of the snow- and firn line rather than the EL. We propose a SAR image enhancement method which improves the contrast between glacier ice and wet snow/firn, allowing better manual delineation of the snow- or firn line. Furthermore, we introduce the term FAR (firn-area ratio) in addition to the known AAR (accumulation-area ratio). The FAR can be used for mass-balance investigations if the radar imagery reveals the FL and not the EL.

Quantitative mass-balance measurements still require in situ data besides remote-sensing data. With this study, conclusions of relative mass-balance fluctuations of Mýrdalsjökull between 1998 and 2004 could be made. In cases where the vertical balance profile is known (e.g. from field measurements), the relative position of the EL allows quantification of the mass-balance conditions. For years where only the FL can be detected, at least a quantitative estimate of the mass balance can be made. The massbalance fluctuations of Mýrdalsjökull are reflected in the change in annual mean air temperatures recorded at nearby weather stations, with the summer temperatures the driving factor. With a mean temperature of $6.3^{\circ} \mathrm{C}$, the year 2004 was unusually warm and shows, with a FAR of 0.43 , a highly negative mass balance. 


\section{ACKNOWLEDGEMENTS}

We thank the European Space Agency (ESA) for supplying ERS and Envisat images within the ESA projects AO2.D116 and ID 142, as well as the Icelandic Meteorological Office for providing meteorological data. We gratefully acknowledge the Scientific Editor, R. Bindschadler, and two anonymous reviewers for providing useful comments.

\section{REFERENCES}

Benson, C.S. 1962. Stratigraphic studies in the snow and firn of the Greenland ice sheet. SIPRE Res. Rep. 70.

Björnsson, H. 1978. The surface area of glaciers in Iceland. Jökull, 28, 31.

Björnsson, H. 1979. Glaciers in Iceland. Jökull, 29, 74-80.

Brown, I.A. 1998. The analysis of glacier firn lines and the firn dynamics of Icelandic ice caps using remote sensing and other data. (PhD thesis, University of Dundee.)

Crabtree, R.D. 1976. Changes in Mýrdalsjökull ice cap, south Iceland: possible uses of satellite imagery. Polar Rec., 18(112), 73-76.

Defense Mapping Agency (DMA). 1990. Topographic map of Iceland, 1:50000. Sheets 1812-II, 1912-I, 1912-III, 1912-IV. Washington DC, Defense Mapping Agency.

de Ruyter de Wildt, M.S., J. Oerlemans and H. Björnsson. 2002. A method for monitoring glacier mass balance using satellite albedo measurements: application to Vatnajökull, Iceland. J. Glaciol., 48(161), 267-278.

de Ruyter de Wildt, M.S. and J. Oerlemans. 2003. Satellite retrieval of mass balance: comparing SAR images with albedo images and in situ mass-balance observations. J. Glaciol., 49(166), 437-448.

Engeset, R.V., J. Kohler, K. Melvold and B. Lundén. 2002. Change detection and monitoring of glacier mass balance and facies using ERS SAR winter images over Svalbard. Int. J. Remote Sens., 23(10), 2023-2050.

Fahnestock, M., R. Bindschadler, R. Kwok and K. Jezek. 1993. Greenland ice sheet surface properties and ice dynamics from ERS-1 SAR imagery. Science, 262(5139), 1530-1534.

Forster, R.R., B.L. Isacks and S.B. Das. 1996. Shuttle imaging radar (SIR-C/X-SAR) reveals near-surface properties of the South Patagonian icefield. J. Geophys. Res., 101(E10), 23,16923,180.

Forster, R.R., L.C. Smith and B.L. Isacks. 1997. Effects of weather events on X-SAR returns from ice fields: case-study of Hielo Patagónico Sur, South America. Ann. Glaciol., 24, 367-374.

Hall, D.K., R.S. Williams, Jr and O. Sigurðsson. 1995. Glaciological observations of Brúarjökull, Iceland, using synthetic aperture radar and thematic mapper satellite data. Ann. Glaciol., 21, 271-276.

Hall, D.K., R.S. Williams, Jr, J.S. Barton, L.C. Smith and J.B. Garvin. 2000. Evaluation of remote-sensing techniques to measure decadal-scale changes of Hofsjökull ice cap, Iceland. J. Glaciol., 46(154), 375-388.

Houghton, J.T. and 7 others. 2001. Climate change 2001: the scientific basis. Contribution of Working Group I to the Third Assessment Report of the Intergovernmental Panel on Climate Change. Cambridge, etc., Cambridge University Press.

Jóhannesson, T. and O. Sigurðsson. 1998. Interpretation of glacier variations in Iceland 1930-1995. Jökull, 45, 27-33.
König, M., J.G. Winther, N.T. Knudsen and T. Guneriussen. 2001. Firn-line detection on Austre Okstindbreen, Norway, with airborne multipolarization SAR. J. Glaciol., 47(157), 251-257.

Larsen, G. 2000. Holocene eruptions within the Katla volcanic system, south Iceland: characteristics and environmental impact. Jökull, 49, 1-28.

Mackintosh, A. 2000. Glacier fluctuations and climate change in Iceland. (PhD thesis, University of Edinburgh.)

Mackintosh, A.N., A.J. Dugmore and A.L. Hubbard. 2002. Holocene climatic changes in Iceland: evidence from modelling glacier length fluctuations at Sólheimajökull. Quat. Int., 91(1), 39-52.

Meier, M.F. and A.S.Post. 1962. Recent variations in mass net budgets of glaciers in western North America. IASH Publ. 58 (Symposium at Obergurgl 1962 - Variations of the Regime of Existing Glaciers), 63-77.

Oerlemans, J. 2001. Glaciers and climate change. Lisse, etc., A.A. Balkema.

Paterson, W.S.B. 1981. The physics of glaciers. Second edition. Oxford, etc., Pergamon Press.

Ramage, J.M., B.L. Isacks and M.M. Miller. 2000. Radar glacier zones in southeast Alaska, U.S.A.: field and satellite observations. J. Glaciol., 46(153), 287-296.

Rott, H. and C. Mätzler. 1987. Possibilities and limits of synthetic aperture radar for snow and glacier surveying. Ann. Glaciol., 9, 195-199.

Sigurðsson, O. 1998. Glacier variations in Iceland 1930-1995. From the database of the Iceland Glaciological Society. Jökull, 45, 3-25.

Sigurðsson, O. 1999. Jöklabreytingar 1930-1960, 1960-1990 og 1995-1996. Jökull, 47, 101-107.

Sigurðsson, O. 2000a. Jöklabreytingar 1930-1960, 1960-1990 og 1996-1997. Jökull, 48, 63-69.

Sigurðsson, O. 2000b. Jöklabreytingar 1930-1960, 1960-1990 og 1997-1998. Jökull, 49, 83-90.

Sigurðsson, O. 2001. Jöklabreytingar 1930-1960, 1960-1990 og 1998-1999 (glacier variations). Jökull, 50, 129-136.

Sigurðsson, O. 2002. Jöklabreytingar 1930-1960, 1960-1990 og 1999-2000 (glacier variations). Jökull, 51, 79-86.

Sigurðsson, O. 2003a. Jöklabreytingar 1930-1960, 1960-1990 og 2000-2001 (glacier variations). Jökull, 52, 61-67.

Sigurðsson, O. 2003b. Jöklabreytingar 1930-1960, 1960-1990 og 2001-2002 (glacier variations). Jökull, 53, 55-62.

Sigurðsson, O. 2004. Jöklabreytingar 1930-1960, 1960-1990 og 2002-2003 (glacier variations). Jökull, 54, 75-83.

Sigurðsson, O. 2005. Jöklabreytingar 1930-1960, 1960-1990 og 2003-2004 (glacier variations). Jökull, 55, 163-170.

Sigvaldason, G.E., K. Annertz and M. Nilsson. 1992. Effect of glacier loading/deloading on volcanism: postglacial volcanic production rate of the Dyngjufjöll area, central Iceland. Bull. Volcanol., 54(5), 385-392.

Smith, L.C., R.R. Forster, B.L. Isacks and D.K. Hall. 1997. Seasonal climatic forcing of alpine glaciers revealed with orbital synthetic aperture radar. J. Glaciol., 43(145), 480-488.

Storvold, R., K.A. Høgda, E. Malnes and I. Lauknes. 2005. SAR firn line detection and correlation to glacial mass balance; Svartisen Glacier, Northern Norway. In Lacoste, H. and L. Ouwehand, eds. Proceedings of the 2004 Envisat \& ERS Symposium, 6-10 September 2004, Salzburg, Austria (ESA SP-572). Noordwijk, European Space Agency.

Williams, R.S., Jr, D.K. Hall and C.S. Benson. 1991. Analysis of glacier facies using satellite techniques. J. Glaciol., 37(125), 120-128. 